\title{
Natural Chalcones in Chinese Materia Medica: Licorice
}

\author{
Danni Wang $\triangle{ }^{1}$, Jing Liang, ${ }^{2}$ Jing Zhang, ${ }^{1}$ Yuefei Wang $\mathbb{D}^{1},{ }^{1}$ and Xin Chai $\mathbb{D}^{1}$ \\ ${ }^{1}$ Tianjin State Key Laboratory of Modern Chinese Medicine, Tianjin University of Traditional Chinese Medicine, \\ Tianjin 301617, China \\ ${ }^{2}$ School of Foreign Language, Chengdu University of Traditional Chinese Medicine, Sichuan 611137, China \\ Correspondence should be addressed to Xin Chai; chaix0622@tjutcm.edu.cn
}

Received 28 August 2019; Accepted 7 February 2020; Published 15 March 2020

Academic Editor: Veronique Seidel

Copyright (C) 2020 Danni Wang et al. This is an open access article distributed under the Creative Commons Attribution License, which permits unrestricted use, distribution, and reproduction in any medium, provided the original work is properly cited.

\begin{abstract}
Licorice is an important Chinese materia medica frequently used in clinical practice, which contains more than 20 triterpenoids and 300 flavonoids. Chalcone, one of the major classes of flavonoid, has a variety of biological activities and is widely distributed in nature. To date, about 42 chalcones have been isolated and identified from licorice. These chalcones play a pivotal role when licorice exerts its pharmacological effects. According to the research reports, these compounds have a wide range of biological activities, containing anticancer, anti-inflammatory, antimicrobial, antioxidative, antiviral, antidiabetic, antidepressive, hepatoprotective activities, and so on. This review aims to summarize structures and biological activities of chalcones from licorice. We hope that this work can provide a theoretical basis for the further studies of chalcones from licorice.
\end{abstract}

\section{Introduction}

Glycyrrhiza, one of the oldest medicinal plants, is often referred to as Chinese licorice, which belongs to the family of Leguminosae $[1,2]$. There are 30 species of licorice distributed all over the world. Three Glycyrrhiza species including Glycyrrhiza uralensis Fisch., Glycyrrhiza inflata Bat., and Glycyrrhiza glabra L. are prescribed as licorice in the Chinese Pharmacopoeia [3, 4]. Licorice, derived from the dried roots and rhizomes of genus Glycyrrhiza, is called "gancao" in China and was firstly recorded in Shennong's Classic of Materia Medica around 2100 BC [5]. It is widely distributed in many provinces of China, such as Xinjiang, Gansu, Inner Mongolia Autonomous Region, Ningxia, and Shanxi, as well as the Siberian region of Russia [5]. As a kind of crucial Chinese materia medica (CMM), licorice has a great many pharmacological effects and is widely used in clinical practice. Licorice is capable of tonifying qi, invigorating spleen and harmonizing stomach, clearing heat, detoxifying, reducing phlegm, relieving cough, alleviating pain, etc. [3,6]. Licorice, which not only has significant efficacy but also has mild and nontoxic properties, can reconcile plenty of CMMs. Therefore, it can be combined with various CMMs to form a variety of Chinese herbal compound prescriptions, such as Guizhi Gancao decoction, Shaoyao Gancao decoction, and Xuefu Zhuyu decoction, thus exerting different effects [3].

Licorice is not only a bulk medicine for traditional Chinese medicine but also a major raw material for Mongolian medicine, or an important component of many folk prescriptions. In addition, the chemical composition of licorice is very complicated. To date, more than 20 triterpenoids and 300 flavonoids have been isolated from licorice [4]. The total flavonoids of licorice are a large class of compounds. At present, many flavonoids have been isolated from licorice, including dihydroflavones, chalcones, isoflavones, and other types of flavonoids. Chalcones, the vital class of secondary metabolites of plant [7], are not only an important synthetic precursor of flavonoids but also a major form of the natural products [8]. Currently, about 42 chalcones have been isolated from licorice. These chalcones play a pivotal role when licorice exerts its pharmacological effects. Numerous studies have indicated that these bioactivities include anticancer [9], antiinflammatory [10], antimicrobial, antiviral [5], antioxidative, hepatoprotective [11], antidiabetic [12], antidepressant activities [13], and so on.

Chalcone compounds and their derivatives are important organic synthesis intermediates. Highlighting the broad 
range of biological activities of chalcones in numerous reports has caused extensive attention. In recent years, people have increasingly studied the components and activities of chalcones in licorice. This work aims to sum up the structures and pharmacological activities of chalcones that have been identified from licorice. This review might provide some dependable experiment gist and a theoretical basis for further research on chalcones in licorice.

\section{The Structures of Chalcones in Licorice}

Chalcones are 1,3-diphenyl-2-propene-1-ones, in which two aromatic rings named as $\mathrm{A}$ and $\mathrm{B}$ ring are linked by a threecarbon $\alpha, \beta$-unsaturated carbonyl system [7]. Chalcones belong to the group of flavonoids, including chalcones and dihydrochalcones (Figure 1). They are not only widespread in nature but also obtained by biosynthesis and chemical synthesis. Since 1988, 42 chalcones including 33 chalcones and 9 dihydrochalcones have been reported in licorice, which were proved to possess a large number of biological activities.

To date, many researchers have analyzed the ingredients in licorice with a variety of methods. For example, based on ultra-performance liquid chromatography-tandem mass spectrometry (UPLC-MS), Jiang et al. detected 19 components in licorice, including isoliquiritin apioside, neoisoliquiritin, and licochalcone A as chalcones [14]. Yin et al. used ultraperformance liquid chromatography-electrospray ionization-quadrupole-time of flight mass spectrometry (UPLC-ESI-Q-TOF-MS) for the rapid analysis of the four chalcones, namely, isoliquiritigenin, isoliquiritin, neoisoliquiritin, and licuraside [15]. By introducing a newly developed high-performance thin-layer chromatography (HPTLC) method, Liu et al. identified several chalcones including isoliquiritin apioside, isoliquiritigenin, isoliquiritin, and so on [16]. Li et al. employed UHPLC-MS to quantify 14 licorice components including five chalcones [17].

To date, about 42 chalcones in licorice have been reported (Table 1). The structures of these compounds were shown in Figure 2.

\section{The Biological Activities of Chalcones in Licorice}

Chalcones in licorice have been reported to manifest different biological activities, including anticancer, anti-inflammatory, antibacterial, antiviral, antioxidative, hepatoprotective, antidiabetic, antidepressant, and other activities (Figure 3). The following is the summary of the biological activities of chalcones in licorice (Table 2).

3.1. Anticancer Activity. Cancer, the enemy of humanity, seriously endangers human life and health. With the aging of the social population structure, environmental pollution, and the prevalence of unhealthy living behaviors such as smoking and unreasonable diet, the situation of cancer will become more intense in a few years. In recent years, phytochemicals from herbal medicine remain a main source of drug discovery [31]. There is no doubt that chalcones in licorice have great influence on the treatment of cancer. Chalcones have the property of electrophiles that interact with nucleophiles in proteins to inhibit the growth of tumor cells. At present, several chalcones from licorice have been demonstrated to possess anticancer property by induction of cell cycle arrest, inhibition of cancer cell metastasis, apoptosis, and autophagy [114].

Isoliquiritigenin is an impactful cancer chemopreventive agent in vitro as well as in vivo. According to the reports, isoliquiritigenin was resistant to multiple tumor cells. Recent study suggested that isoliquiritigenin induced apoptosis in A549 non-small-cell lung cancer cells by crosstalk between protein 53 (p53), B-cell lymphoma-2 (Bcl-2) family proteins, caspase cascades, and protein kinase B (Akt) survival pathways [32]. It also caused DNA damage and inhibited ataxia-telangiectasia mutated (ATM) expression leading to G2/M phase arrest and apoptosis in oral squamous cell carcinoma [33]. Isoliquiritigenin induced apoptosis in renal cell carcinoma Caki cells via the generation of ROS, resulting in induction of p53 expression and inhibition of the signal transducer and activator of transcription 3 (STAT3) signaling pathway [34]. Moreover, isoliquiritigenin affected WIF1 gene and downregulated $\kappa$-catenin signal, resulting in the undergoing arrest of breast cancer cells at the G0/G1 phase [35]. In prostate cancer, it affected expression of protein B1, cyclin-dependent kinase 1 (CDK1), and other related molecules in the G2/M cell cycle of PC-3 and 22RV1 cells [31].

Licochalcone A, a characteristic chalcone isolated from licorice roots [36], was proved to be resistant to many types of cancer cells through different mechanisms. Induction of mitochondrial dysfunction is one of the main pathways leading to apoptosis by licochalcone $\mathrm{A}$. It was found that it induced activation of caspases via the mitochondrial pathway and then mediated its antiproliferative and apoptotic effects of oral squamous cell carcinoma by inhibiting Sp1 and Sp1-mediated signaling pathways [37]. Licochalcone A inhibited glioma cell growth by mediating cell cycle arrest at G0/G1 and G2/M phases and induced cell death by inducing mitochondrial dysfunction $[38,39]$. Licochalcone A induced apoptosis of gastric cancer cells via the caspase-dependent mitochondrial pathway and exerted G2 cell cycle arrest through the regulation of $\mathrm{G} 2 / \mathrm{M}$ phase checkpoint proteins [40]. Additionally, it handled activation of the LC3-II signaling pathway while inhibiting the phosphatidylinositol 3kinase (PI3K)/Akt/mammalian target of the rapamycin (mTOR) signaling pathway that promoted autophagy and apoptosis in cells [41]. Licochalcone A caused G2 and lateG1 arrests in androgen-independent PC-3 prostate cancer cells by affecting the expression of proliferating cell nuclear antigen (PCNA), DNA polymerase $\delta, \mathrm{Rb}$ and $\mathrm{E} 2 \mathrm{~F}$, cyclins B1 and D1, and so on, which led to apoptosis [42].

Licochalcone $\mathrm{B}$ led to $\mathrm{S}$-phase arrest, decreased the expression of cyclin A, CDK1, CDK2 mRNA, Bcl-2, survivin, and cell division cycle 25 (Cdc25A and Cdc25B) proteins, induced downregulation of antiapoptotic proteins (Bid, Bcl-xl, and Mcl-1), and also caused the loss of 


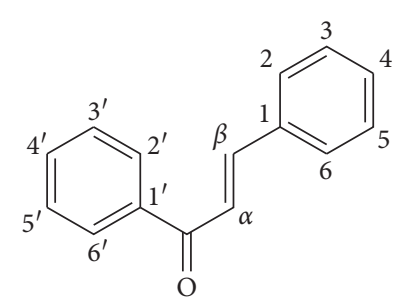

(a)<smiles>O=C(CCc1ccccc1)c1ccccc1</smiles>

(b)

Figure 1: Basic framework of chalcone and dihydrochalcone.

TABLE 1: The sources of chalcones from licorice.

\begin{tabular}{|c|c|c|c|}
\hline Number & Name & Source & Reference \\
\hline $\mathrm{C} 1$ & Isoliquiritin apioside & $\begin{array}{l}\text { G. glabra L. } \\
\text { G. uralensis Fisch. } \\
\text { G. inflata Bat. } \\
\text { G. glabra L. }\end{array}$ & {$[16,17]$} \\
\hline $\mathrm{C} 2$ & Licuraside & $\begin{array}{l}\text { G. uralensis Fisch. } \\
\text { G. inflata Bat. } \\
\text { G. glabra L. }\end{array}$ & [17] \\
\hline $\mathrm{C} 3$ & Isoliquiritin & $\begin{array}{l}\text { G. uralensis Fisch. } \\
\text { G. inflata Bat. }\end{array}$ & [16-18] \\
\hline $\mathrm{C} 4$ & Butein-4-O- $\beta$-D-glucopyranoside & $\begin{array}{l}\text { G. uralensis Fisch. } \\
\text { G. glabra L. }\end{array}$ & [19] \\
\hline $\mathrm{C} 5$ & Neoisoliquiritin & $\begin{array}{l}\text { G. uralensis Fisch. } \\
\text { G. inflata Bat. } \\
\text { G. glabra L. }\end{array}$ & {$[14,16,20]$} \\
\hline C6 & Isoliquiritigenin & $\begin{array}{l}\text { G. uralensis Fisch. } \\
\text { G. inflata Bat. }\end{array}$ & {$[16,17,21-24]$} \\
\hline $\mathrm{C} 7$ & Homobutein & $\begin{array}{l}\text { G. uralensis Fisch. } \\
\text { G. uralensis Fisch. }\end{array}$ & [18] \\
\hline $\mathrm{C} 8$ & Echinatin & $\begin{array}{l}\text { G. glabra L. } \\
\text { G. inflata Bat. } \\
\text { G. glabra L. }\end{array}$ & {$[10,18,21,22,25]$} \\
\hline C9 & Licochalcone A & $\begin{array}{l}\text { G. uralensis Fisch. } \\
\text { G. inflata Bat. } \\
\text { G. uralensis Fisch. }\end{array}$ & {$[10,14,17]$} \\
\hline $\mathrm{C} 10$ & Licochalcone B & $\begin{array}{l}\text { G. glabra L. } \\
\text { G. inflata Bat. }\end{array}$ & {$[10,21,22,25]$} \\
\hline $\mathrm{C} 11$ & 5-(1,1-Dimethylallyl)-3,4,4'-trihydroxy-2-methoxychalcone (DTM) & $\begin{array}{l}\text { G. uralensis Fisch. } \\
\text { G. inflata Bat. }\end{array}$ & {$[10,21]$} \\
\hline $\mathrm{C} 12$ & Licochalcone C & $\begin{array}{l}\text { G. glabra L. } \\
\text { G. inflata Bat. }\end{array}$ & {$[21,22,26]$} \\
\hline $\mathrm{C} 13$ & Licochalcone D & G. inflata Bat. & [22] \\
\hline $\mathrm{C} 14$ & Licochalcone E & G. inflata Bat. & {$[21,22]$} \\
\hline $\mathrm{C} 15$ & Isobavachalcone & $\begin{array}{l}\text { G. glabra L. } \\
\text { G. inflata Bat. }\end{array}$ & {$[21,27]$} \\
\hline $\mathrm{C} 16$ & Kanzonol C & G. inflata Bat. & {$[21]$} \\
\hline $\mathrm{C} 17$ & Corylifol B & G. inflata Bat. & [21] \\
\hline $\mathrm{C} 18$ & Morachalcone A & G. glabra L. & {$[25]$} \\
\hline $\mathrm{C} 19$ & $2,3^{\prime}, 4,4^{\prime}$-Tetrahydroxy-3,5' -diprenylchalcone & G. glabra L. & [25] \\
\hline $\mathrm{C} 20$ & Kanzonol B & $\begin{array}{l}\text { G. glabra L. } \\
\text { G. inflata Bat. }\end{array}$ & {$[21,27]$} \\
\hline $\mathrm{C} 21$ & $3,3^{\prime}, 4,4^{\prime}$-Tetrahydroxy-2'-methoxy-5-prenylchalcone & G. glabra L. & {$[25]$} \\
\hline $\mathrm{C} 22$ & Licochalcone G & G. glabra L. & [28] \\
\hline $\mathrm{C} 23$ & $2^{\prime}, 3,4^{\prime}$-Trihydroxy- $3^{\prime}-\gamma, \gamma$-dimethylallyl- $6^{\prime \prime}, 6^{\prime \prime}$-dimethylpyrano $\left[2^{\prime \prime}, 3^{\prime \prime}: 4,5\right]$ chalcone & G. glabra L. & [25] \\
\hline $\mathrm{C} 24$ & $3,4,3^{\prime}, 4^{\prime}$-Tetrahydroxychalcone & G. inflata Bat. & {$[21]$} \\
\hline $\mathrm{C} 25$ & $3,4,3^{\prime}, 4^{\prime}$-Tetrahydroxy-2-methoxychalcone & G. glabra L. & [16] \\
\hline $\mathrm{C} 26$ & Licoagrochalcone A & $\begin{array}{l}\text { G. glabra L. } \\
\text { G. inflata Bat. }\end{array}$ & {$[21,27]$} \\
\hline
\end{tabular}


TABle 1: Continued.

\begin{tabular}{|c|c|c|c|}
\hline Number & Name & Source & Reference \\
\hline $\mathrm{C} 27$ & Licoagrochalcone B & G. glabra L. & {$[26]$} \\
\hline C28 & Licoagrochalcone C & $\begin{array}{l}\text { G. glabra L. } \\
\text { G. inflata Bat. }\end{array}$ & {$[21,26]$} \\
\hline C29 & Licoagrochalcone D & G. glabra L. & {$[26]$} \\
\hline $\mathrm{C} 30$ & Glypallichalcone & G. glabra L. & [29] \\
\hline $\mathrm{C} 31$ & Paratocarpin A & G. glabra L. & [23] \\
\hline C32 & Paratocarpin B & G. glabra L. & [23] \\
\hline $\mathrm{C} 33$ & 4-Hydroxylonchocarpin & G. glabra L. & [27] \\
\hline C34 & Dihydroisoliquiritigenin & G. inflate Bat. & {$[24]$} \\
\hline $\mathrm{C} 35$ & Glycybridin A & G. glabra L. & {$[30]$} \\
\hline $\mathrm{C} 36$ & Kanzonol Y & G. glabra L. & {$[26]$} \\
\hline $\mathrm{C} 37$ & 1-(2',4'-Dihydroxyphenyl)-2-hydroxy-3-(4" -hydroxyphenyl)-1-propanone & G. glabra L. & {$[25]$} \\
\hline $\mathrm{C} 38$ & $2,3^{\prime}, 4,4^{\prime}, \alpha$-Pentahydroxy-3,5' -diprenyl-dihydrochalcone & G. glabra L. & {$[25]$} \\
\hline $\mathrm{C} 39$ & $2,3^{\prime}, 4,4^{\prime}, \alpha$-Pentahydroxy-3-prenyl-dihydrochalcone & G. glabra L. & [25] \\
\hline $\mathrm{C} 40$ & Glycybridin B & G. glabra L. & {$[30]$} \\
\hline $\mathrm{C} 41$ & Glycybridin C & G. glabra L. & {$[25,30]$} \\
\hline $\mathrm{C} 42$ & $2^{\prime}, 4^{\prime}$-Dihydroxydihydrochalcone-4-O- $\beta$-D-glucopyranoside & G. uralensis Fisch. & [19] \\
\hline
\end{tabular}

mitochondrial membrane potential (MMP) [43, 44]. However, it enhanced Bax expression, activated caspase-3, and cleaved poly ADP-ribose polymerase (PARP) protein [44]. In addition, it attenuated migration, adhesion, and invasion of cancer cells accompanied with the downregulated protein expression of MMP-9 and nuclear translocation of nuclear factor- $\kappa \mathrm{B}(\mathrm{NF}-\kappa \mathrm{B})$ [115].

Similar to licochalcone B, licochalcones $\mathrm{C}$ and D induced apoptosis by altering the expression of Bcl-2 family member genes and activating the caspase-mediated cell death signaling pathway $[45,46]$. Meanwhile, licochalcone D induced apoptosis through mitochondrial pathway and blocked cell migration and invasion into surrounding tissues by reducing the activity and expression of MMP-2 and MMP-9 [46]. In addition to increasing the expression of proteins (proapoptotic factors, caspase-3, and PARP), suppressing the constitutive $\mathrm{NF}-\kappa \mathrm{B}$ activation, and downregulating Bcl-2 and Bax, licochalcone $\mathrm{E}$ reduced tumor growth and metastasis through inhibiting tube formation of vascular endothelial cells [47-49]. Same as licochalcone D, kanzonol C could inhibit MMP-2 secretion from tumor cells [50]. Unlike the preceding compounds, isobavachalcone induced apoptosis through increasing the expression of tumor necrosis factor-related apoptosis-inducing ligand-receptor 2 (TRAIL-R2) [51].

Echinatin triggered apoptosis of esophageal squamous cell carcinoma by inducing intrinsic and extrinsic apoptosis pathways through ROS- and ER-stress-mediated signaling [52]. Additionally, another study has demonstrated that it inhibited cell proliferation and induced apoptosis by targeting epidermal growth factor receptor (EGFR) and mesenchymal-to-epithelial transition (MET) factor in gefitinibsensitive and gefitinib-resistant non-small-cell lung cancer (NSCLC) cells [53]. Isoliquiritin apioside, as an antigenotoxic substance, showed obvious anticancer effect by preventing $\mathrm{H}_{2} \mathrm{O}_{2}$ - and 4NQO- induced DNA damage [54]. Paratocarpin A showed evident anti-invasive activity on MCF-7/6 mammary carcinoma cells [55]. Apart from the above compounds, 4-hydroxylonchocarpin and kanzonol Y also showed anticancer activity [56-58].
3.2. Anti-Inflammatory Activity. The inflammatory reaction is a common clinical pathological process that could be born in various parts of body tissues and organs [116]. According to the duration of inflammation, it is divided into two stages: acute and chronic inflammation [56]. In the more serious inflammatory diseases, especially when the pathogenic microorganisms spread in the body, there is obvious systemic reaction [60]. So far, the treatment of inflammation encounters a lot of difficulties. How to safely and effectively treat inflammation is also an issue that should be solved urgently. As a commonly used CMM for the treatment of inflammation, licorice has notable anti-inflammatory effect. Triterpenes and flavonoids from licorice might cure different types of inflammation, especially chalcones [6]. NF- $\kappa \mathrm{B}$ and mitogen-activated protein kinase (MAPK) pathways were proved to be important for chalcones to exert anti-inflammatory activity.

Isoliquiritigenin, a natural chalcone extracted from licorice, has been well studied for its anti-inflammatory activity [117]. Confirmed by cell experiments, isoliquiritigenin inhibited inducible nitric oxide synthase (iNOS) and cyclooxygenase-2 (COX-2) protein expressions and iNOS, COX-2, tumor necrosis factor- $\alpha$ (TNF- $\alpha$ ), and interleukin-6 (IL-6) transcriptions by inhibiting degradation and phosphorylation of inhibitor $\kappa \mathrm{B}-\alpha(\mathrm{I} \kappa \mathrm{B} \alpha)$ and blocking activation of $\mathrm{NF}-\kappa \mathrm{B}$ [60]. In other cases, isoliquiritigenin suppressed the receptor activator of nuclear factor-B ligand (RANKL)-induced inflammatory symptom via inhibiting the receptor activator of nuclear factor-B ligand-tumor necrosis factor receptor-associated factor 6 (RANK-TRAF6), MAPK, I $\kappa \mathrm{B} \alpha / \mathrm{NF}-\kappa \mathrm{B}$, and activator protein-1 (AP-1) signaling pathways [61]. Isoliquiritigenin inhibited activation of NF- $\kappa \mathrm{B}$ and formation of lipopolysaccharide (LPS)-induced toll-like receptor 4 /myeloid differentiation protein 2 (TLR4/MD-2) complexes, which further led to suppressing LPS-induced activation of signaling cascades [62]. In addition, isoliquiritigenin and isoliquiritin, to a certain extent, could mediate anti-inflammatory responses of LPS-induced macrophage activation via increasing heme oxygenase-1 
<smiles>O=C(Cc1ccc(OC2OC(CO)[C@@H](O)C(O)C2OC2OCC(O)(CO)[C@H]2O)cc1)c1ccc(O)cc1O</smiles><smiles>[R]c1cc(/C=C/C(=O)c2ccc(O)cc2O)ccc1O</smiles>

$6 \mathrm{R}=\mathrm{H}$

$7 \mathrm{R}=\mathrm{OMe}$<smiles>O=C(/C=C/c1ccc(O)cc1)c1ccc(OC2OC(CO)C(O)C(O)C2O)cc1OC1OC(CO)C(O)(CO)C1O</smiles>
2<smiles>[R]c1cc(C(=O)/C=C/c2cc(Br)c(O)c(OC)c2[R])ccc1O</smiles>

$8 \mathrm{R}_{1}=\mathrm{H} \quad \mathrm{R}_{2}=\mathrm{H} \quad \mathrm{R}_{3}=\mathrm{H}$

$9 \begin{array}{lll}\mathrm{R}_{1}=\mathrm{H} & \mathrm{R}_{2}=\mathrm{H} & \mathrm{R}_{3}=\chi\end{array}$

$10 \mathrm{R}_{1}=\mathrm{H} \quad \mathrm{R}_{2}=\mathrm{OH} \quad \mathrm{R}_{3}=\mathrm{H}$

$11 \mathrm{R}_{1}=\mathrm{H} \quad \mathrm{R}_{2}=\mathrm{OH} \quad \mathrm{R}_{3}=\chi$

$12 \mathrm{R}_{1}=\mathrm{H} \quad \mathrm{R}_{2}=$ prenyl $\mathrm{R}_{3}=\mathrm{H}$

$13 \mathrm{R}_{1}=$ prenyl $\mathrm{R}_{2}=\mathrm{OH} \quad \mathrm{R}_{3}=\mathrm{H}$

$14 \mathrm{R}_{1}=\mathrm{H} \quad \mathrm{R}_{2}=\mathrm{H} \quad \mathrm{R}_{3}=$<smiles>COc1c(/C=C/C(=O)c2cc(O)c(O)c(CC=C(C)C)c2)ccc(O)c1O</smiles><smiles>[R]c1c(-c2c(C(=O)O)ccc(O)c2[R])ccc(O)c1CC=C(C)C</smiles>

$27 \mathrm{R}_{1}=\mathrm{OH} \quad \mathrm{R}_{2}=\mathrm{H} \quad \mathrm{R}_{3}=\mathrm{OCH}_{3}$

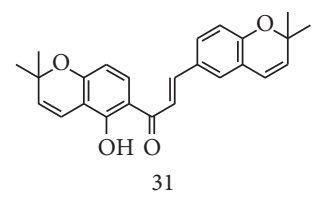<smiles>[R]c1ccc(CC(O)C(=O)c2cc([R])c(O)cc2O)cc1[R]</smiles>

$36 \mathrm{R}_{1}=$ prenyl $\mathrm{R}_{2}=\mathrm{H} \quad \mathrm{R}_{3}=$ prenyl $37 \mathrm{R}_{1}=\mathrm{H} \quad \mathrm{R}_{2}=\mathrm{OH} \quad \mathrm{R}_{3}=\mathrm{H}$<smiles>C=CC(C)(C)c1cc(/C=C/C(=O)c2ccc(O)cc2O)c(OC)cc1O</smiles>

22<smiles>COC(=O)c1ccc(O)cc1/C=C/c1ccc2c(c1)C=CC(C)O2</smiles><smiles></smiles><smiles>[R]c1cc(CC(O)C(=O)c2ccc(O)c([R])c2O)cc([R])c1O</smiles>

$38 \mathrm{R}_{1}=$ prenyl $\mathrm{R}_{2}=$ prenyl $\mathrm{R}_{3}=\mathrm{OH}$

$39 \mathrm{R}_{1}=$ prenyl $\mathrm{R}_{2}=\mathrm{H} \quad \mathrm{R}_{3}=\mathrm{OH}$

$40 \mathrm{R}_{1}=\mathrm{H} \quad \mathrm{R}_{2}=\mathrm{H} \quad \mathrm{R}_{3}=$ prenyl

$41 \mathrm{R}_{1}=$ prenyl $\mathrm{R}_{2}=\mathrm{H} \quad \mathrm{R}_{3}=$ prenyl

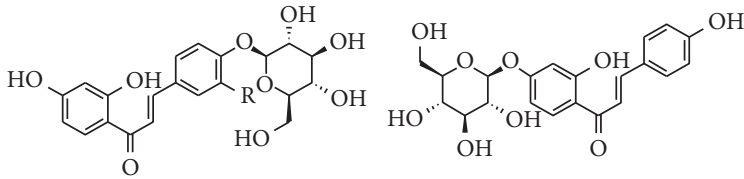

$$
\begin{aligned}
& 3 \mathrm{R}=\mathrm{H} \\
& 4 \mathrm{R}=\mathrm{OH}
\end{aligned}
$$<smiles>[R]c1c(/C=C/C(=O)c2ccc(O)c(CC=C(C)C)c2O)cc(Br)c(O)c1[R]</smiles>

$15 \mathrm{R}_{1}=\mathrm{H} \quad \mathrm{R}_{2}=\mathrm{H} \quad \mathrm{R}_{3}=\mathrm{H}$

$16 \mathrm{R}_{1}=$ prenyl $\mathrm{R}_{2}=\mathrm{H} \quad \mathrm{R}_{3}=\mathrm{H}$

$17 \mathrm{R}_{1}=\mathrm{OH} \quad \mathrm{R}_{2}=\mathrm{H} \quad \mathrm{R}_{3}=\mathrm{H}$

$18 \mathrm{R}_{1}=\mathrm{H} \quad \mathrm{R}_{2}=\mathrm{OH} \mathrm{R} \mathrm{R}_{3}=\mathrm{H}$

$19 \mathrm{R}_{1}=\mathrm{OH} \quad \mathrm{R}_{2}=\mathrm{H} \quad \mathrm{R}_{3}=$ prenyl<smiles>CC(C)=CCc1c(O)ccc(C(=O)C=Cc2cc(O)c3c(c2)C=CC(C)(C)O3)c1O</smiles><smiles>[R]c1c(/C=C/C(=O)c2ccc(O)c(O)c2)ccc(O)c1O</smiles>

$24 \mathrm{R}=\mathrm{H}$

$25 \mathrm{R}=\mathrm{OMe}$<smiles>COc1c(/C=C/C(=O)c2ccc(O)cc2)ccc2c1CC(C(C)(C)O)O2</smiles><smiles>COc1ccc(C(=O)C=Cc2ccc(O)cc2OC)cc1</smiles><smiles>O=C(CCc1ccc(O)cc1)c1ccc(O)cc1</smiles><smiles>CC1(C)C=Cc2cc(C(O)C(=O)c3ccc(O)cc3O)ccc2O1</smiles>

Figure 2: The structures of chalcones from licorice.

(HO-1) and nuclear factor erythroid 2-related factor 2 (Nrf2) expression and inhibiting $\mathrm{I} \kappa \mathrm{B} \alpha$ phosphorylation and degradation [59]. Additionally, isoliquiritigenin prevented nonsteroidal anti-inflammatory drug (NSAID)-induced small intestinal damage by the inhibition of NOD-like receptor (NLR) family and pyrin domain containing 3 (NLRP3) inflammasome activation [63] and ameliorated the dextran sulfate sodium (DSS)-induced colitis through inhibiting MAPK pathway [64]. It also has been demonstrated that isoliquiritigenin exerted anti-inflammatory 


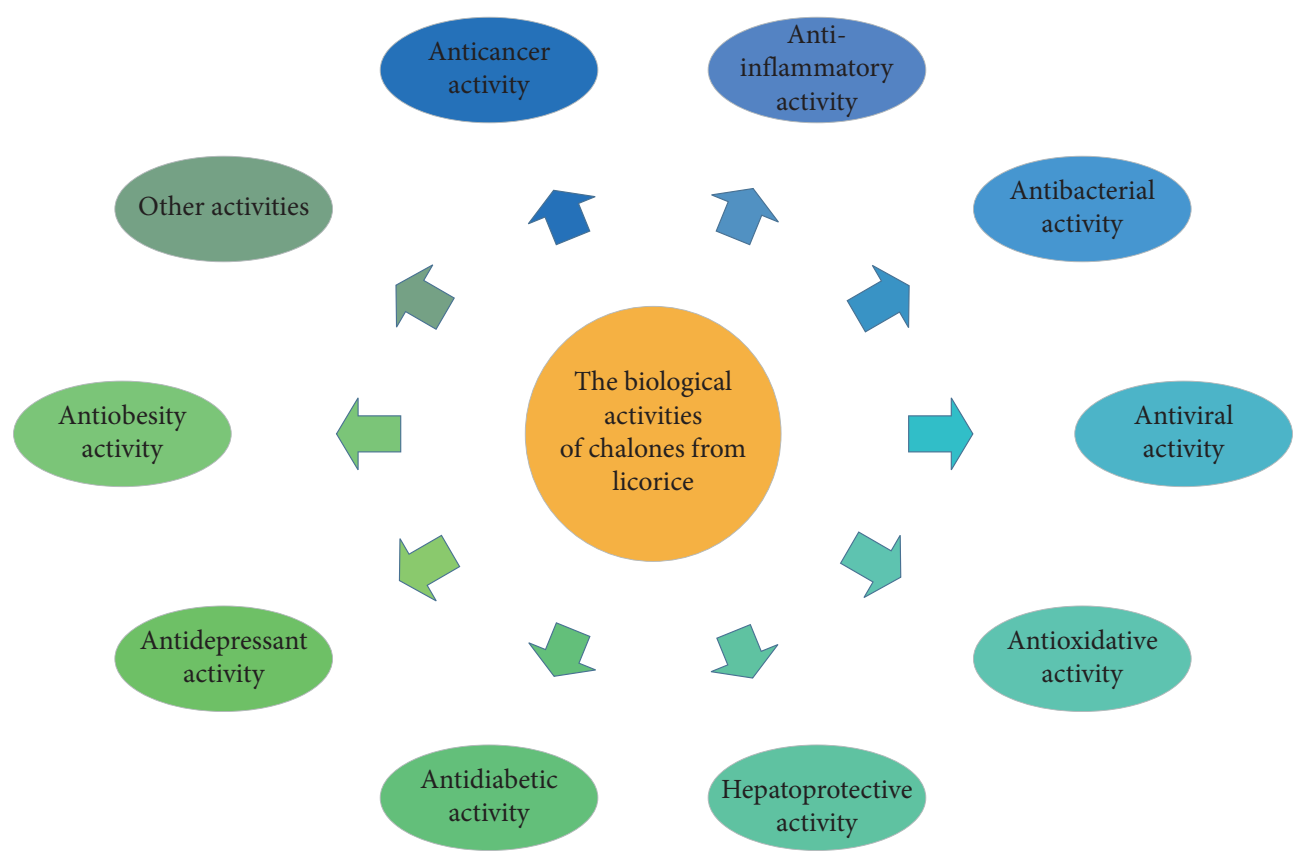

FIGURE 3: The biological activities of chalcones from licorice.

TABLE 2: The biological activities of chalcones from licorice.

\begin{tabular}{|c|c|c|}
\hline Biological activity & Compounds & Reference \\
\hline Anticancer & $\begin{array}{c}\text { Isoliquiritigenin } \\
\text { Isoliquiritin } \\
\text { Licochalcone A } \\
\text { Licochalcone B } \\
\text { Licochalcone C } \\
\text { Licochalcone D } \\
\text { Licochalcone E } \\
\text { Kanzonol C } \\
\text { Isobavachalcone } \\
\text { Echinatin } \\
\text { Isoliquiritin apioside } \\
\text { Paratocarpin A } \\
\text { 4-Hydroxylonchocarpin } \\
\text { Kanzonol Y }\end{array}$ & $\begin{array}{c}31-35] \\
{[32]} \\
{[36-42]} \\
{[43,44]} \\
{[45,46]} \\
{[45,46]} \\
{[47-49]} \\
{[50]} \\
{[51]} \\
{[52,53]} \\
{[54]} \\
{[55]} \\
{[56,57]} \\
{[58]}\end{array}$ \\
\hline Anti-inflammatory & $\begin{array}{c}\text { Isoliquiritin } \\
\text { Isoliquiritigenin } \\
\text { Homobutein } \\
\text { Echinatin } \\
\text { Licochalcone A } \\
\text { Licochalcone B } \\
\text { Licochalcone C } \\
\text { Licochalcone D } \\
\text { Licochalcone E } \\
\text { Isobavachalcone } \\
\text { Morachalcone A } \\
\text { Kanzonol B } \\
\text { DTM } \\
\text { Licoagrochalcone C } \\
\text { 4-Hydroxylonchocarpin }\end{array}$ & $\begin{array}{c}{[59]} \\
{[59-68]} \\
{[68]} \\
{[10,69,70]} \\
{[10,70-75]} \\
{[10,21,69,70]} \\
{[21,69,76,77]} \\
{[69,70]} \\
{[21,77]} \\
{[78,79]} \\
{[80]} \\
{[10,79]} \\
{[10,21]} \\
{[10,21]} \\
{[78,81]}\end{array}$ \\
\hline
\end{tabular}


TABLE 2: Continued.

\begin{tabular}{|c|c|c|}
\hline Biological activity & Compounds & Reference \\
\hline \multirow{5}{*}{ Antibacterial } & Isoliquiritigenin & {$[82,83]$} \\
\hline & Licochalcone A & [84-88] \\
\hline & Isobavachalcone & [89-91] \\
\hline & Kanzonol C & {$[89,90]$} \\
\hline & 4-Hydroxylonchocarpin & {$[89]$} \\
\hline \multirow{5}{*}{ Antiviral } & Isoliquiritigenin & {$[28,92]$} \\
\hline & Licochalcone A & {$[92,93]$} \\
\hline & Isobavachalcone & {$[94]$} \\
\hline & Echinatin & {$[28]$} \\
\hline & Kanzonol Y & [95] \\
\hline \multirow{11}{*}{ Antioxidative } & Isoliquiritigenin & {$[26,96]$} \\
\hline & Licochalcone A & {$[97,98]$} \\
\hline & Licochalcone B & {$[10,22]$} \\
\hline & Licochalcone C & [99] \\
\hline & Licochalcone D & {$[22]$} \\
\hline & Isobavachalcone & {$[100]$} \\
\hline & Echinatin & {$[10]$} \\
\hline & DTM & {$[10]$} \\
\hline & Paratocarpin B & {$[26]$} \\
\hline & Glypallichalcone & {$[101]$} \\
\hline & Dihydroisoliquiritigenin & {$[102]$} \\
\hline \multirow{7}{*}{ Hepatoprotective } & Isoliquiritigenin & [103] \\
\hline & Echinatin & {$[104]$} \\
\hline & Licochalcone A & {$[104]$} \\
\hline & Licochalcone B & [103-105] \\
\hline & Licochalcone $\mathrm{E}$ & {$[106]$} \\
\hline & Licoagrochalcone A & {$[103]$} \\
\hline & $3,4,3^{\prime}, 4^{\prime}$-Tetrahydroxychalcone & {$[103]$} \\
\hline \multirow{6}{*}{ Antidiabetic } & Isoliquiritigenin & {$[107,108]$} \\
\hline & Licochalcone E & {$[12]$} \\
\hline & Echinatin & [109] \\
\hline & Isobavachalcone & [110] \\
\hline & Kanzonol C & {$[21]$} \\
\hline & Licoagrochalcone A & {$[21]$} \\
\hline \multirow{6}{*}{ Antiobesity } & Kanzonol C & {$[21]$} \\
\hline & Licoagrochalcone A & {$[21]$} \\
\hline & Isobavachalcone & [110] \\
\hline & Isoliquiritin apioside & [111] \\
\hline & Isoliquiritigenin & {$[111]$} \\
\hline & Licochalcone A & {$[112,113]$} \\
\hline
\end{tabular}

effect through inhibiting eotaxin-1 secretion and suppressing IL-1, IL-8, and caspase-1 production [65-67].

Many studies have shown that licochalcone A was proved to perform anti-inflammatory activity. In acute lung injury models, it suppressed activation of NF- $\kappa \mathrm{B}$ and phosphorylation of p38MAPK and extracellular regulated protein kinases (ERK) [71]. Licochalcone A reduced LPS-induced NF- $\kappa \mathrm{B}$ transactivation by inhibiting phosphorylation of p65 at serine 276 and interaction of p65 with p300 [72]. The compound not only indicated an anti-inflammatory effect on IL- $1 \beta$-stimulated chondrocytes by activating the Nrf2 signaling pathway [73] but also activated Keap1-Nrf2 signaling to inhibit arthritis by enhancing phosphorylation and expression of p62 at serine 349 [74]. ERK and p38 signaling pathways might play a role in attenuation of allergic airway inflammation by licochalcone $\mathrm{A}$ [75].

Several compounds of chalcones were discovered to strongly inhibit nitric oxide (NO), IL-6, and prostaglandin
$\mathrm{E}_{2}\left(\mathrm{PGE}_{2}\right)$ secretion. On one hand, echinatin, licochalcones A-E, isobavachalcone, morachalcone A, DTM, licoagrochalcone $\mathrm{C}$, and 4-hydroxylonchocarpin have been demonstrated to show significant inhibitory activity on LPSinduced NO production $[10,21,69,70,78,80]$. On the other hand, these compounds also have other different anti-inflammatory mechanisms. Licochalcones A and B, echinatin, and DTM inhibited the production of IL- 6 and PGE 2 in LPSinduced macrophage cells. Furthermore, licochalcones B and $\mathrm{D}$ reduced LPS-induced production of TNF- $\alpha$ and monocyte chemotactic protein 1 (MCP-1) [10, 69, 70].

Licochalcone $\mathrm{C}$ played a vital role in sepsis-induced inflammation through repressing $\mathrm{NF}-\kappa \mathrm{B}$ translocation and several kinds of downstream molecules, including iNOS, intercellular adhesion molecule-1 (ICAM-1), as well as vascular cell adhesion molecule-1 (VCAM-1). Meanwhile, it might upregulate the PI3K/Akt/eNOS signaling pathway 
[76]. Similar to licochalcone $\mathrm{C}$, licochalcone E reduced expression of inducible enzymes (iNOS and COX-2) and proinflammatory cytokines via the suppression of NF- $\kappa \mathrm{B}$ and AP-1 transcriptional activity [77]. Isobavachalcone and kanzonol $\mathrm{B}$ suppressed the production of $\mathrm{PGE}_{2}$ and $\mathrm{NO}$ and downregulated the expression of iNOS and COX-2 through suppressing $\mathrm{I} \kappa \mathrm{B} \alpha$ degradation in LPS-activated microglia [79]. Histone deacetylase enzymes (HDACs), potential drug targets for natural chalcones, were employed to treat cancer and inflammation. Isoliquiritigenin and homobutein might suppress both NF- $\kappa \mathrm{B}$ and HDAC activities [68]. Through inhibiting the binding of LPS to TLR4 on immune cells and increasing the polarization of M1 macrophages to M2 macrophages, 4-hydroxylonchocarpin attenuated colitis in mice [81]. The anti-inflammatory mechanism of morachalcone A was related to the activation of MAPKs (p38, ERK, and JNK) and NF- $\kappa$ B pathways, particularly decrease of nuclear translocation of NF- $\kappa \mathrm{B}$ p65 subunit [80]. Kanzonol B, DTM, and licoagrochalcone $\mathrm{C}$ revealed efficacious inhibitory activity on NF- $\kappa$ B transcription [10].

3.3. Antibacterial Activity. There are many antibacterial drugs in the market today. However, with the abuse of antibacterial drugs, the resistance of bacteria is increasing. Therefore, it is crucial to find the new, safe, and effective antibacterial drugs. Some compounds from licorice were proved to have antibacterial activity.

On the basis of previous research studies, isoliquiritigenin had obvious inhibitory effect on methicillin-resistant Staphylococcus aureus and Ralstonia solanacearum [82, 83]. Licochalcone $\mathrm{A}$, as one of the vital antibacterial components in licorice, was resistant to both bacterial and fungal infections $[118,119]$. The study also showed promising antifungal activity of licochalcone A against Trichophyton rubrum via inhibiting important antifungal targets of ergosterol synthesis, cell wall synthesis, and glyoxylate cycle [119]. It has been reported to display good activity against Staphylococcus aureus biofilm [84]. Licochalcone A exhibited in vitro inhibitory effect on human pathogenic Mycobacteria species (Mycobacterium tuberculosis, M. bovis, M. kansasii, M. xenophii, and M. marinum) and Legionella species (Legionella bozemanni, L. dumoffi, L. feelei, L. longbeacheae, L. wadsworthii, L. gormanii, and L. micdadei), which might be a candidate for treating severe lung infections [85]. Besides, licochalcone A revealed the effects of resisting to all Gram-positive bacteria tested, including spore-forming bacteria, such as genera Bacillus and Clostridium, and toxin-producing bacteria, such as Bacillus cereus and Ralstonia aureus [118]. And it affected the growth of Streptococcus suis by inhibiting biofilm formation and hemolysin lyase secretion [86]. Licochalcone A also inhibited the growth of Helicobacter pylori [87]. Furthermore, it was an effective antifungal agent that might act in synergy with nystatin to inhibit the growth of Candida albicans so as to treat candidiasis [88].

A study investigated effects of isobavachalcone, kanzonol C, and 4-hydroxylonchocarpin on 22 strains of microbial species, such as Gram-positive bacteria (Streptococcus faecalis, Staphylococcus aureus, Bacillus cereus, Bacillus megaterium, Bacillus stearothermophilus, and Bacillus subtilis), Gram-negative bacteria (Citrobacter freundii, Enterobacter aerogenes, Enterobacter cloacae, Escherichia coli, Klebsiella pneumonia, Morganella morganii, Proteus mirabilis, Proteus vulgaris, Pseudomonas aeruginosa, Shigella dysenteriae, Shigella flexneri, and Salmonella typhi) and fungi (Candida albicans, Candida glabrata, Microsporum auditorium, and Trichophyton rubrum) [89]. Isobavachalcone and kanzonol C could prevent the growth of all the 22 tested microbial species, and 4-hydroxylonchocarpin might suppress the growth of six species of Gram-positive bacteria, four species of fungi, and seven species of Gram-negative bacteria [89]. Isobavachalcone, kanzonol C, and 4-hydroxylonchocarpin also inhibited the reverse transcriptase activity and revealed the antimycobacterial activity against Mycobacterium tuberculosis $\mathrm{H}_{37} \mathrm{Rv}[90,120]$. Isobavachalcone also showed inhibitory activity against Candida albicans and Candida neoformans [91].

3.4. Antiviral Activity. Licorice is a universal CMM from several prescriptions, which has been proved to inhibit viral infection [121]. At present, there are some antiviral studies on the chalcone compounds from licorice. The components studied include isoliquiritigenin, licochalcone A, isobavachalcone, echinatin, and kanzonol Y. Isoliquiritigenin and licochalcone A evinced anti-HCV activity [92, 93]. Isobavachalcone had potent antiporcine reproductive and respiratory syndrome virus (PRRSV) activity in vitro by inhibiting PRRSV replication at the postentry stage of PRRSV infection [94]. Echinatin and isoliquiritigenin showed strong inhibitory effects on influenza viral strains, H1N1, H9N2, and novel H1N1 [28]. Kanzonol Y had antidengue virus (DENV) activity [95].

3.5. Antioxidative Activity. Excessive free radicals will accelerate human aging and bring on other diseases [122]. Therefore, enhancing the body's antioxidant capacity is critical to human health. The phenolic hydroxyl structure of chalcones is a good proton donor, which can terminate the oxidative damage by combining with a radical [123]. There are a few chalcone compounds in licorice with antioxidant capacity.

Isoliquiritigenin, as an abundant and forceful antioxidant toward low-density lipoprotein (LDL) oxidation, could attenuate atherosclerosis [96]. Isoliquiritigenin and paratocarpin $\mathrm{B}$ were found to be the most powerful antioxidant agents by an authentic peroxynitrite antioxidant assay [26]. Licochalcones $\mathrm{A}, \mathrm{B}$, and D, DTM, and isobavachalcone inhibited NADPHinduced microsomal lipid peroxidation [10, 22]. Isobavachalcone also suppressed ascorbate-, $t$ - $\mathrm{BuOOH}-$, and $\mathrm{CCl}_{4}$-induced microsomal lipid peroxidation, and NADHdependent and ascorbate-induced mitochondrial lipid peroxidation [100]. Studies manifested that echinatin and licochalcone $\mathrm{B}$ possessed the strong scavenging activity toward $\mathrm{ABTS}^{+}$ radical [10]. Licochalcones $\mathrm{B}$ and $\mathrm{D}$ strongly suppressed superoxide anion production and expressed powerful scavenging activity on DPPH radical [22]. Licochalcone A protected skin 
cells from oxidative stress by activating Nrf2-signaling, resulting in increased expression of HO-1 and glutamatecysteine ligase regulatory subunit (GCLM) and reduction of intracellular ROS concentration [97]. Moreover, licochalcones $\mathrm{A}$ and $\mathrm{C}$ increased the expression of antioxidant enzymes including superoxide dismutase (SOD), catalase (CAT), and glutathione peroxidase (GPx) proteins that were closely related to antioxidant mechanisms [98, 99]. Glypallichalcone, the inhibitor of LDL oxidation, reduced cholesterol levels through modulation of $\beta-1$ adrenergic receptor [101]. Dihydroisoliquiritigenin was used as a neuroprotectant against glutamate-induced oxidative stress in a mouse-derived hippocampal neuronal cell line (HT22) [102].

3.6. Hepatoprotective Activity. Liver is a vital organ that performs many metabolic functions in the body such as detoxification, glycogen storage, and protein synthesis [124]. $\mathrm{CCl}_{4}$ is a chemical substance that is severely toxic to hepatocytes [125]. Also, overuse of acetaminophen (APAP) could cause drug-induced liver toxicity [126]. The natural ingredients of CMMs are considered to be an effective and safe alternative way to treat hepatocyte damage [11]. A few chalcone constituents in licorice have been proved to possess significant hepatoprotective activity.

For example, echinatin and licochalcones $\mathrm{A}$ and $\mathrm{B}$ showed Nrf2 activation activities on HepG2C8 cells in AREluciferase reporter assay and a promising hepatoprotective effect on $\mathrm{CCl}_{4}$-induced acute liver injury in the ICR mice model [104]. Additionally, isoliquiritigenin, licochalcone B, and licoagrochalcone $\mathrm{A}$ possessed a remarkably potent protective effect against both $\mathrm{CCl}_{4}$ - and APAP-induced HepG2 cell injuries. 3,4,3', $4^{\prime}$-Tetrahydroxychalcone also showed significantly potent activity against $\mathrm{CCl}_{4}$-induced liver injury [103]. Moreover, studies have demonstrated that licochalcone B might protect hepatocytes from alcohol-induced cell damage by reducing apoptosis, inhibiting oxidative stress, and upregulating Erk-Nrf2 [105]. Licochalcone E basically exhibited its protective role for treating hepatotoxicity through the peroxisome proliferator-activated receptor- $\gamma($ PPAR- $\gamma$ )/NF- $\kappa$ B-mediated pathway [106].

3.7. Antidiabetic Activity. Diabetes is a group of metabolic diseases characterized by hyperglycemia [127]. Longstanding hyperglycemia in diabetes leads to various tissue dysfunctions [128]. At present, drugs for the treatment of this disease are urgently needed to be developed. As confirmed by the experiment, extracts from licorice have a protective effect on diabetic nephropathy [129].

Through the oral glucose tolerance test, the hypoglycemic effect of isoliquiritigenin on normal Swiss albino male mice was reported [107]. Another finding demonstrated that isoliquiritigenin diminished high glucose-induced mesangial matrix accumulation through retarding transforming growth factor (TGF)- $\beta 1$-SMAD signaling transduction [108]. Angiotensin-converting enzyme (ACE) plays a prominent role in hypertension, heart failures, myocardial infarction, and diabetic nephropathy. The study showed that echinatin has been proved to show a certain inhibitory effect on ACE in vitro
[109]. Furthermore, licochalcone E enhanced expression of PPAR- $\gamma$ through irritating Akt signals as well as functions as a PPAR- $\gamma$ partial agonist, which improved hyperlipidemia and hyperglycemia under diabetic conditions [12]. Kanzonol C, licoagrochalcone $\mathrm{A}$, and isobavachalcone as inhibitors of protein tyrosine phosphate $1 \mathrm{~B}$ (PTP1B) were potential candidates for treating type II diabetes [21, 110].

3.8. Antiobesity Activity. Obesity is a globally epidemic chronic metabolic disease, and the proportion of obese people continues to rise due to changes in lifestyle and diet. Obesity poses a series of potential safety hazard, so the use of antiobesity drugs can help improve the health of patients. Kanzonol C, licoagrochalcone A, and isobavachalcone were found to be PTP1B inhibitors for treatment of obesity $[21,110]$. Isoliquiritin apioside and isoliquiritigenin, as sources of pancreatic lipase (PL) inhibitors for preventing obesity, could lower the plasma total triglycerides and total cholesterol [111]. Licochalcone A had an inhibitory effect on adipocyte differentiation and lipogenesis via the downregulation of PPAR- $\gamma$, CCAAT/enhancer binding protein $\alpha$ $(\mathrm{C} / \mathrm{EBP} \alpha)$, and sterol regulatory element-binding protein $1 \mathrm{c}$ (SREBP-1c) in 3T3-L1 preadipocytes [112]. And other results demonstrated that licochalcone A was effective to reduce obesity and could recover metabolic homeostasis by inducing adipocyte browning [113].

3.9. Other Activities. Isoliquiritigenin has been detected to have antiplatelet action [130], protective effect on cerebral ischemia injury [131], and estrogen-like [132], neuroprotective [133], and antimelanogenic [134] activities. Licochalcone A has been demonstrated to possess antispasmodic [135], antileishmanial [136], antimalarial [137], and osteogenic activities [138]. Isoliquiritin was studied to produce significant antidepressant-like effect [13].

\section{Conclusion}

Phytochemical constituents especially flavonoids are largely considered to be beneficial for human health and disease prevention. As a category of nontoxic and effective natural ingredients, chalcones are proved to possess lots of biological activities and medicinal properties. To date, about 42 chalcones in licorice have been isolated and identified, and more new structures will be unveiled. Meanwhile, most of chalcones in licorice have been widely and deeply studied for their various activities, such as anticancer, anti-inflammatory, antimicrobial, antiviral, antioxidative, hepatoprotective, antidiabetic, and antiobesity activities. However, it will be a long way to further validate the pharmacological action and develop new drug. As chalcones in licorice are deeply explored and fully utilized, it will be served as a broad prospect for development and utilization of licorice.

\section{Conflicts of Interest}

The authors declare that there are no conflicts of interest regarding the publication of this paper. 


\section{Authors' Contributions}

Danni Wang and Jing Liang contributed equally to this work.

\section{Acknowledgments}

This work was supported by the National Natural Science Foundation of China (81873192), the Science \& Technology Development Fund of Tianjin Education Commission for Higher Education (2018ZD02), and National Key Research and Development Project of China (2018YFC1707905).

\section{References}

[1] J. Wang, W. Gao, L. Zhang, and L. Huang, "Establishment and quality assessment of tissue cultures in Glycyrrhiza uralensis Fisch," Applied Biochemistry and Biotechnology, vol. 169, no. 2, pp. 588-594, 2013.

[2] J. A. Ramilowski, S. Sawai, H. Seki et al., "Glycyrrhiza uralensis transcriptome landscape and study of phytochemicals," Plant and Cell Physiology, vol. 54, no. 5, pp. 697-710, 2013.

[3] Editorial Board of Chinese Pharmacopoeia, Pharmacopoeia of the People's Republic of China, Chemistry and Industry Press, Beijing, China, 2015.

[4] Q. Zhang and M. Ye, "Chemical analysis of the Chinese herbal medicine Gan-Cao (licorice)," Journal of Chromatography A, vol. 1216, no. 11, pp. 1954-1969, 2009.

[5] L. Wang, R. Yang, B. Yuan, Y. Liu, and C. Liu, "The antiviral and antimicrobial activities of licorice, a widely-used Chinese herb," Acta Pharmaceutica Sinica B, vol. 5, no. 4, pp. 310315, 2015.

[6] R. Yang, B.-C. Yuan, Y.-S. Ma, S. Zhou, and Y. Liu, “The antiinflammatory activity of licorice, a widely used Chinese herb," Pharmaceutical Biology, vol. 55, no. 1, pp. 5-18, 2017.

[7] A.-M. Katsori and D. Hadjipavlou-Litina, "Recent progress in therapeutic applications of chalcones," Expert Opinion on Therapeutic Patents, vol. 21, no. 10, pp. 1575-1596, 2011.

[8] P. Singh, A. Anand, and V. Kumar, "Recent developments in biological activities of chalcones: a mini review," European Journal of Medicinal Chemistry, vol. 85, pp. 758-777, 2014.

[9] X. Shi, M. Zou, J. He, H. Xie, and X. Li, "Studies on the identification of constituents in ethanol extract of radix glycyrrhizae and their anticancer activity," African Journal of Traditional, Complementary and Alternative Medicines, vol. 11, no. 2, pp. 334-338, 2014.

[10] Y. Fu, J. Chen, Y.-J. Li, Y.-F. Zheng, and P. Li, “Antioxidant and anti-inflammatory activities of six flavonoids separated from licorice," Food Chemistry, vol. 141, no. 2, pp. 1063-1071, 2013.

[11] H. Z. Huo, B. Wang, Y. K. Liang, Y. Y. Bao, and Y. Gu, "Hepatoprotective and antioxidant effects of licorice extract against $\mathrm{CCl}_{4}$-induced oxidative damage in rats," International Journal of Molecular Sciences, vol. 12, no. 10, pp. 6529-6543, 2011.

[12] H. G. Park, E. J. Bak, G.-H. Woo et al., "Licochalcone E has an antidiabetic effect," The Journal of Nutritional Biochemistry, vol. 23, no. 7, pp. 759-767, 2012.

[13] W. Wang, X. Hu, Z. Zhao et al., "Antidepressant-like effects of liquiritin and isoliquiritin from Glycyrrhiza uralensis in the forced swimming test and tail suspension test in mice,"
Progress in Neuro-Psychopharmacology and Biological Psychiatry, vol. 32, no. 5, pp. 1179-1184, 2008.

[14] Z. Jiang, Y. Wang, Y. Zheng, J. Yang, and L. Zhang, "Ultra high performance liquid chromatography coupled with triple quadrupole mass spectrometry and chemometric analysis of licorice based on the simultaneous determination of saponins and flavonoids," Journal of Separation Science, vol. 39, no. 15, pp. 2928-2940, 2016.

[15] Q. Yin, P. Wang, A. Zhang, H. Sun, X. Wu, and X. Wang, "Ultra-performance LC-ESI/quadrupole-TOF MS for rapid analysis of chemical constituents of Shaoyao-Gancao decoction," Journal of Separation Science, vol. 36, no. 7, pp. 1238-1246, 2013.

[16] X. Liu, Q. Li, C. Lv et al., "Combination of the advantages of chromatographic methods based on active components for the quality evaluation of licorice," Journal of Separation Science, vol. 38, no. 24, pp. 4180-4186, 2015.

[17] G. Li, D. Nikolic, and R. B. van Breemen, "Identification and chemical standardization of licorice raw materials and dietary supplements using UHPLC-MS/MS," Journal of Agricultural and Food Chemistry, vol. 64, no. 42, pp. 8062-8070, 2016.

[18] S. Ji, Z. Li, W. Song et al., "Bioactive constituents of Glycyrrhiza uralensis (licorice): discovery of the effective components of a traditional herbal medicine," Journal of Natural Products, vol. 79, no. 2, pp. 281-292, 2016.

[19] M. Cheng, L. Ding, H. Kan et al., "Isolation, structural elucidation and in vitro hepatoprotective activity of flavonoids from Glycyrrhiza uralensis," Journal of Natural Medicines, vol. 73, no. 4, pp. 847-854, 2019.

[20] H. Zhang, Y. Liu, and R. Zhang, "Study on the compounds of flavonoids in Glycyrrhiza uralensis," Acta Pharmaceutica Sinica, vol. 29, no. 6, pp. 471-474, 1994.

[21] Y. Lin, Y. Kuang, K. Li et al., "Screening for bioactive natural products from a 67-compound library of Glycyrrhiza inflata," Bioorganic \& Medicinal Chemistry, vol. 25, no. 14, pp. 3706-3713, 2017.

[22] H. Haraguchi, H. Ishikawa, K. Mizutani, Y. Tamura, and T. Kinoshita, "Antioxidative and superoxide scavenging activities of retrochalcones in Glycyrrhiza inflata," Bioorganic \& Medicinal Chemistry, vol. 6, no. 3, pp. 339-347, 1998.

[23] Y.-W. Chin, H.-A. Jung, Y. Liu et al., “Anti-oxidant constituents of the roots and stolons of licorice (Glycyrrhiza glabra)," Journal of Agricultural and Food Chemistry, vol. 55, no. 12, pp. 4691-4697, 2007.

[24] L. Sun and Y. Yang, "Isolation and identification of chemical constituents of Glycyrrhiza inflata bat," Anhui Medical and Pharmaceutical Journal, vol. 17, no. 7, pp. 1121-1123, 2013.

[25] M. Kuroda, Y. Mimaki, S. Honda, H. Tanaka, S. Yokota, and T. Mae, "Phenolics from Glycyrrhiza glabra roots and their PPAR- $\gamma$ ligand-binding activity," Bioorganic \& Medicinal Chemistry, vol. 18, no. 2, pp. 962-970, 2010.

[26] W. Li, Y. Asada, and T. Yoshikawa, "Flavonoid constituents from Glycyrrhiza glabra hairy root cultures," Phytochemistry, vol. 55, no. 5, pp. 447-456, 2000.

[27] Y. Asada, W. Li, and T. Yoshikawa, "Isoprenylated flavonoids from hairy root cultures of Glycyrrhiza glabra," Phytochemistry, vol. 47, no. 3, pp. 389-392, 1998.

[28] T. T. Dao, P. H. Nguyen, H. S. Lee et al., "Chalcones as novel influenza A (H1N1) neuraminidase inhibitors from Glycyrrhiza inflata," Bioorganic \& Medicinal Chemistry Letters, vol. 21, no. 1, pp. 294-298, 2011. 
[29] L. Cai, R. Zhang, B. Wang et al., "Studies on the chemical constituents of Glycyrrhiza pallidiflora Maxim," Acta Pharmaceutica Sinica, vol. 21, no. 1, pp. 748-751, 1992.

[30] K. Li, S. Ji, W. Song et al., "Glycybridins A-K, bioactive phenolic compounds from Glycyrrhiza glabra," Journal of Natural Products, vol. 80, no. 2, pp. 334-346, 2017.

[31] B. Zhang, Y. Lai, Y. Li et al., "Antineoplastic activity of isoliquiritigenin, a chalcone compound, in androgen-independent human prostate cancer cells linked to G2/M cell cycle arrest and cell apoptosis," European Journal of Pharmacology, vol. 821, pp. 57-67, 2018.

[32] Y. Zhou and W. S. Ho, "Combination of liquiritin, isoliquiritin and isoliquirigenin induce apoptotic cell death through upregulating p53 and p21 in the A549 non-small cell lung cancer cells," Oncology Reports, vol. 31, no. 1, pp. 298-304, 2014.

[33] S.-M. Hsia, C.-C. Yu, Y.-H. Shih et al., "Isoliquiritigenin as a cause of DNA damage and inhibitor of ataxia-telangiectasia mutated expression leading to G2/M phase arrest and apoptosis in oral squamous cell carcinoma," Head \& Neck, vol. 38, no. S1, pp. E360-E371, 2016.

[34] D.-H. Kim, J. E. Park, I. G. Chae, G. Park, S. Lee, and K.-S. Chun, "Isoliquiritigenin inhibits the proliferation of human renal carcinoma caki cells through the ROS-mediated regulation of the Jak2/STAT3 pathway," Oncology Reports, vol. 38, no. 1, pp. 575-583, 2017.

[35] P. R. Dandawate, D. Subramaniam, R. A. Jensen, and S. Anant, "Targeting cancer stem cells and signaling pathways by phytochemicals: novel approach for breast cancer therapy," Seminars in Cancer Biology, vol. 40-41, pp. 192-208, 2016.

[36] D. Liu, X. Huo, L. Gao, J. Zhang, H. Ni, and L. Cao, "NF- $\kappa B$ and Nrf2 pathways contribute to the protective effect of licochalcone A on dextran sulphate sodium-induced ulcerative colitis in mice," Biomedicine \& Pharmacotherapy, vol. 102, pp. 922-929, 2018.

[37] J. J. Cho, J.-I. Chae, G. Yoon et al., "Licochalcone A, a natural chalconoid isolated from Glycyrrhiza inflata root, induces apoptosis via $\mathrm{Sp} 1$ and $\mathrm{Sp} 1$ regulatory proteins in oral squamous cell carcinoma," International Journal of Oncology, vol. 45, no. 2, pp. 667-674, 2014.

[38] W. J. Lu, G. J. Wu, R. J. Chen et al., "Licochalcone A attenuates glioma cell growth in vitro and in vivo through cell cycle arrest," Food \& Function, vol. 9, no. 8, pp. 4500-4507, 2018.

[39] K. Kuramoto, S. Suzuki, H. Sakaki et al., "Licochalcone A specifically induces cell death in glioma stem cells via mitochondrial dysfunction," FEBS Open Bio, vol. 7, no. 6, pp. 835-844, 2017.

[40] X.-Y. Xiao, M. Hao, X.-Y. Yang et al., "Licochalcone A inhibits growth of gastric cancer cells by arresting cell cycle progression and inducing apoptosis," Cancer Letters, vol. 302, no. 1, pp. 69-75, 2011.

[41] L. Xue, W. J. Zhang, Q. X. Fan et al., "Licochalcone A inhibits $\mathrm{PI} 3 \mathrm{~K} / \mathrm{Akt} / \mathrm{mTOR}$ signaling pathway activation and promotes autophagy in breast cancer cells," Oncology Letters, vol. 15, no. 2, pp. 1869-1873, 2018.

[42] Y. Fu, T.-C. Hsieh, J. Guo et al., "Licochalcone-A, a novel flavonoid isolated from licorice root (Glycyrrhiza glabra), causes G2 and late-G1 arrests in androgen-independent PC3 prostate cancer cells," Biochemical and Biophysical Research Communications, vol. 322, no. 1, pp. 263-270, 2004.

[43] T.-H. Kang, G. Yoon, I.-A. Kang, H.-N. Oh, J.-I. Chae, and J.-H. Shim, "Natural compound licochalcone B induced extrinsic and intrinsic apoptosis in human skin melanoma
(A375) and squamous cell carcinoma (A431) cells," Phytotherapy Research, vol. 31, no. 12, pp. 1858-1867, 2017.

[44] X. Yuan, T. Li, E. Xiao et al., "Licochalcone B inhibits growth of bladder cancer cells by arresting cell cycle progression and inducing apoptosis," Food and Chemical Toxicology, vol. 65, pp. 242-251, 2014.

[45] P. Wang, X. Yuan, Y. Wang, H. Zhao, X. Sun, and Q. Zheng, "Licochalcone $\mathrm{C}$ induces apoptosis via B-cell lymphoma 2 family proteins in T24 cells," Molecular Medicine Reports, vol. 12, no. 5, pp. 7623-7628, 2015.

[46] L. Si, X. Yan, W. Hao et al., "Licochalcone D induces apoptosis and inhibits migration and invasion in human melanoma A375 cells," Oncology Reports, vol. 39, no. 5, pp. 2160-2170, 2018.

[47] S.-J. Yu, I.-A. Cho, K.-R. Kang et al., "Licochalcone-E induces caspase-dependent death of human pharyngeal squamous carcinoma cells through the extrinsic and intrinsic apoptotic signaling pathways," Oncology Letters, vol. 13, no. 5, pp. 3662-3668, 2017.

[48] S. J. Kwon, S. Y. Park, G. T. Kwon et al., "Licochalcone E present in licorice suppresses lung metastasis in the 4T1 mammary orthotopic cancer model," Cancer Prevention Research, vol. 6, no. 6, pp. 603-613, 2013.

[49] H. J. Chang, G. Yoon, J. S. Park et al., "Induction of apoptosis by the licochalcone $\mathrm{E}$ in endothelial cells via modulation of NF- $\kappa$ B and Bcl-2 family," Biological \& Pharmaceutical Bulletin, vol. 30, no. 12, pp. 2290-2293, 2007.

[50] B. Ngameni, M. Touaibia, R. Patnam et al., "Inhibition of MMP-2 secretion from brain tumor cells suggests chemopreventive properties of a furanocoumarin glycoside and of chalcones isolated from the twigs of Dorstenia turbinata," Phytochemistry, vol. 67, no. 23, pp. 2573-2579, 2006.

[51] E. Szliszka, D. Jaworska, M. Ksek et al., "Targeting death receptor TRAIL-R2 by chalcones for TRAIL-induced apoptosis in cancer cells," International Journal of Molecular Sciences, vol. 13, no. 11, pp. 15343-15359, 2012.

[52] A.-W. Kwak, J.-S. Choi, M.-H. Lee et al., "Retrochalcone echinatin triggers apoptosis of esophageal squamous cell carcinoma via ROS- and ER stress-mediated signaling pathways," Molecules, vol. 24, no. 22, p. 4055, 2019.

[53] H. N. Oh, M. H. Lee, E. Kim et al., "Dual inhibition of EGFR and MET by echinatin retards cell growth and induces apoptosis of lung cancer cells sensitive or resistant to gefitinib," Phytotherapy Research, vol. 34, no. 2, pp. 388-400, 2019.

[54] P. Kaur, S. Kaur, N. Kumar, B. Singh, and S. Kumar, "Evaluation of antigenotoxic activity of isoliquiritin apioside from Glycyrrhiza glabra L," Toxicology in Vitro, vol. 23, no. 4, pp. 680-686, 2009.

[55] V. S. Parmar, M. E. Bracke, J. Philippe et al., "Anti-invasive activity of alkaloids and polyphenolics in vitro," Bioorganic \& Medicinal Chemistry, vol. 5, no. 8, pp. 1609-1619, 1997.

[56] V. R. Yadav, S. Prasad, B. Sung, and B. B. Aggarwal, "The role of chalcones in suppression of NF- $\kappa \mathrm{B}$-mediated inflammation and cancer," International Immunopharmacology, vol. 11, no. 3, pp. 295-309, 2011.

[57] V. Kuete, B. Ngameni, B. Wiench et al., "Cytotoxicity and mode of action of four naturally occuring flavonoids from the genus dorstenia: gancaonin Q, 4-hydroxylonchocarpin, 6-prenylapigenin, and 6,8-diprenyleriodictyol," Planta Medica, vol. 77, no. 18, pp. 1984-1989, 2011.

[58] T. Fukai, B.-S. Cai, K. Maruno, Y. Miyakawa, M. Konishi, and T. Nomura, "An isoprenylated flavanone from 
Glycyrrhiza glabra and rec-assay of licorice phenols," Phytochemistry, vol. 49, no. 7, pp. 2005-2013, 1998.

[59] R. Wang, C. Y. Zhang, L. P. Bai et al., "Flavonoids derived from liquorice suppress murine macrophage activation by up-regulating heme oxygenase-1 independent of Nrf2 activation," International Immunopharmacology, vol. 28, no. 2, pp. 917-924, 2015.

[60] J.-Y. Kim, S. J. Park, K.-J. Yun, Y.-W. Cho, H.-J. Park, and K.-T. Lee, "Isoliquiritigenin isolated from the roots of Glycyrrhiza uralensis inhibits LPS-induced iNOS and COX-2 expression via the attenuation of NF- $\kappa \mathrm{B}$ in RAW 264.7 macrophages," European Journal of Pharmacology, vol. 584, no. 1, pp. 175-184, 2008.

[61] L. Zhu, H. Wei, Y. Wu et al., "Licorice isoliquiritigenin suppresses RANKL-induced osteoclastogenesis in vitro and prevents inflammatory bone loss in vivo," The International Journal of Biochemistry \& Cell Biology, vol. 44, no. 7, pp. 1139-1152, 2012.

[62] H. Honda, Y. Nagai, T. Matsunaga et al., "Glycyrrhizin and isoliquiritigenin suppress the LPS sensor toll-like receptor 4/ MD-2 complex signaling in a different manner," Journal of Leukocyte Biology, vol. 91, no. 6, pp. 967-976, 2012.

[63] S. Nakamura, T. Watanabe, T. Tanigawa et al., "Isoliquiritigenin ameliorates indomethacin-induced small intestinal damage by inhibiting NOD-like receptor family, pyrin domain-containing 3 inflammasome activation," Pharmacology, vol. 101, no. 5-6, pp. 236-245, 2018.

[64] Y. H. Choi, J.-K. Bae, H.-S. Chae et al., "Isoliquiritigenin ameliorates dextran sulfate sodium-induced colitis through the inhibition of MAPK pathway," International Immunopharmacology, vol. 31, pp. 223-232, 2016.

[65] B. Jayaprakasam, S. Doddaga, R. Wang, D. Holmes, J. Goldfarb, and X.-M. Li, "Licorice flavonoids inhibit eotaxin-1 secretion by human fetal lung fibroblastsin vitro," Journal of Agricultural and Food Chemistry, vol. 57, no. 3, pp. 820-825, 2009.

[66] H. Honda, Y. Nagai, T. Matsunaga et al., "Isoliquiritigenin is a potent inhibitor of NLRP3 inflammasome activation and diet-induced adipose tissue inflammation," Journal of Leukocyte Biology, vol. 96, no. 6, pp. 1087-1100, 2014.

[67] Y. Wu, X. Chen, X. Ge et al., "Isoliquiritigenin prevents the progression of psoriasis-like symptoms by inhibiting NF- $\kappa \mathrm{B}$ and proinflammatory cytokines," Journal of Molecular Medicine, vol. 94, no. 2, pp. 195-206, 2016.

[68] B. Orlikova, M. Schnekenburger, M. Zloh, F. Golais, M. Diederich, and D. Tasdemir, "Natural chalcones as dual inhibitors of HDACs and NF- $\kappa$ B," Oncology Reports, vol. 28, no. 3, pp. 797-805, 2012.

[69] S.-J. Kim, C. G. Kim, S.-R. Yun, J.-K. Kim, and J.-G. Jun, "Synthesis of licochalcone analogues with increased antiinflammatory activity," Bioorganic \& Medicinal Chemistry Letters, vol. 24, no. 1, pp. 181-185, 2014.

[70] J.-I. Furusawa, M. Funakoshi-Tago, T. Mashino et al., "Glycyrrhiza inflata-derived chalcones, licochalcone A, licochalcone $\mathrm{B}$ and licochalcone $\mathrm{D}$, inhibit phosphorylation of NF- $\kappa$ B p65 in LPS signaling pathway," International Immunopharmacology, vol. 9, no. 4, pp. 499-507, 2009.

[71] X. Chu, X. Ci, M. Wei et al., "Licochalcone A inhibits lipopolysaccharide-induced inflammatory response in vitro and in vivo," Journal of Agricultural and Food Chemistry, vol. 60, no. 15, pp. 3947-3954, 2012.

[72] J.-I. Furusawa, M. Funakoshi-Tago, K. Tago et al., "Licochalcone A significantly suppresses LPS signaling pathway through the inhibition of NF- $\kappa \mathrm{B}$ p 65 phosphorylation at serine 276," Cellular Signalling, vol. 21, no. 5, pp. 778-785, 2009.

[73] T. Jia, J. Qiao, D. Guan, and T. Chen, "Anti-inflammatory effects of licochalcone A on IL- $1 \beta$-stimulated human osteoarthritis chondrocytes," Inflammation, vol. 40, no. 6, pp. 1894-1902, 2017.

[74] X. Su, T. Li, Z. Liu et al., "Licochalcone A activates Keap1Nrf2 signaling to suppress arthritis via phosphorylation of p62 at serine 349," Free Radical Biology and Medicine, vol. 115, pp. 471-483, 2018.

[75] X. Chu, L. Jiang, M. Wei et al., “Attenuation of allergic airway inflammation in a murine model of asthma by licochalcone A," Immunopharmacology and Immunotoxicology, vol. 35, no. 6, pp. 653-661, 2013.

[76] S. Franceschelli, M. Pesce, A. Ferrone et al., "Biological effect of licochalcone $\mathrm{C}$ on the regulation of PI3K/Akt/eNOS and $\mathrm{NF}-\kappa \mathrm{B} / \mathrm{iNOS} / \mathrm{NO}$ signaling pathways in $\mathrm{H} 9 \mathrm{c} 2$ cells in response to LPS stimulation," International Journal of Molecular Sciences, vol. 18, no. 4, p. 690, 2017.

[77] H. Lee, H. Cho, D. Lim, Y.-H. Kang, K. Lee, and J. Park, "Mechanisms by which licochalcone E exhibits potent antiinflammatory properties: studies with phorbol ester-treated mouse skin and lipopolysaccharide-stimulated murine macrophages," International Journal of Molecular Sciences, vol. 14, no. 6, pp. 10926-10943, 2013.

[78] J. P. Dzoyem, A. H. L. Nkuete, B. Ngameni, and J. N. Eloff, "Anti-inflammatory and anticholinesterase activity of six flavonoids isolated from Polygonum and Dorstenia species," Archives of Pharmacal Research, vol. 40, no. 10, pp. 11291134, 2017.

[79] D. Kim, H. Li, Y. Han, J. Jeong, H. Lee, and J.-H. Ryu, "Modulation of inducible nitric oxide synthase expression in LPS-stimulated BV-2 microglia by Prenylated chalcones from Cullen corylifolium (L.) medik. Through inhibition of I- $\kappa \mathrm{B} \alpha$ degradation," Molecules, vol. 23, no. 1, p. 109, 2018.

[80] X. Yao, D. Wu, N. Dong et al., "Moracin C, a phenolic compound isolated from Artocarpus heterophyllus, suppresses lipopolysaccharide-activated inflammatory responses in murine raw264.7 macrophages," International Journal of Molecular Sciences, vol. 17, no. 8, p. 1199, 2016.

[81] H.-M. Jang, G.-D. Kang, T. K. Van Le, S.-M. Lim, D.-S. Jang, and D.-H. Kim, "4-Methoxylonchocarpin attenuates inflammation by inhibiting lipopolysaccharide binding to tolllike receptor of macrophages and M1 macrophage polarization," International Immunopharmacology, vol. 45, pp. 90-97, 2017.

[82] R. Gaur, V. K. Gupta, P. Singh, A. Pal, M. P. Darokar, and R. S. Bhakuni, "Drug resistance reversal potential of isoliquiritigenin and liquiritigenin isolated from Glycyrrhiza glabra against methicillin-resistant Staphylococcus aureus (MRSA)," Phytotherapy Research, vol. 30, no. 10, pp. 1708$1715,2016$.

[83] X. Zhao, W. Mei, M. Gong, W. Zuo, H. Bai, and H. Dai, "Antibacterial activity of the flavonoids from Dalbergia odorifera on Ralstonia solanacearum," Molecules, vol. 16, no. 12, pp. 9775-9782, 2011.

[84] F. Shen, X. Tang, Y. Wang et al., "Phenotype and expression profile analysis of Staphylococcus aureus biofilms and planktonic cells in response to licochalcone A," Applied Microbiology and Biotechnology, vol. 99, no. 1, pp. 359-373, 2015.

[85] A. Friis-Moller, M. Chen, K. Fuursted, S. Brøgger Christensen, and A. Kharazmi, "In vitro antimycobacterial and 
antilegionella activity of licochalcone A from Chinese licorice roots," Planta Medica, vol. 68, no. 5, pp. 416-419, 2002.

[86] H. Hao, W. Hui, P. Liu et al., "Effect of licochalcone A on growth and properties of Streptococcus suis," PLoS One, vol. 8, no. 7, Article ID e67728, 2013.

[87] T. Fukai, A. Marumo, K. Kaitou, T. Kanda, S. Terada, and T. Nomura, "Anti-helicobacter pylori flavonoids from licorice extract," Life Sciences, vol. 71, no. 12, pp. 1449-1463, 2002.

[88] C. Messier and D. Grenier, "Effect of licorice compounds licochalcone A, glabridin and glycyrrhizic acid on growth and virulence properties of Candida albicans," Mycoses, vol. 54, no. 6, pp. 801-806, 2011.

[89] A. T. Mbaveng, B. Ngameni, V. Kuete et al., "Antimicrobial activity of the crude extracts and five flavonoids from the twigs of Dorstenia barteri (Moraceae)," Journal of Ethnopharmacology, vol. 116, no. 3, pp. 483-489, 2008.

[90] V. Kuete, B. Ngameni, A. T. Mbaveng, B. Ngadjui, J. J. M. Meyer, and N. Lall, "Evaluation of flavonoids from Dorstenia barteri for their antimycobacterial, antigonorrheal and anti-reverse transcriptase activities," Acta Tropica, vol. 116, no. 1, pp. 100-104, 2010.

[91] H. N. ElSohly, A. S. Joshi, A. C. Nimrod, L. A. Walker, and A. M. Clark, "Antifungal chalcones from Maclura tinctoria," Planta Medica, vol. 67, no. 1, pp. 87-89, 2001.

[92] M. Adianti, C. Aoki, M. Komoto et al., "Anti-hepatitis C virus compounds obtained from Glycyrrhiza uralensis and other Glycyrrhiz aspecies," Microbiology and Immunology, vol. 58, no. 3, pp. 180-187, 2014.

[93] Y. Sekine-Osajima, N. Sakamoto, M. Nakagawa et al., "Two flavonoids extracts from Glycyrrhizae radix inhibitin vitrohepatitis C virus replication," Hepatology Research, vol. 39, no. 1, pp. 60-69, 2009.

[94] H.-M. Wang, T.-X. Liu, T.-Y. Wang et al., "Isobavachalcone inhibits post-entry stages of the porcine reproductive and respiratory syndrome virus life cycle," Archives of Virology, vol. 163, no. 5, pp. 1263-1270, 2018.

[95] C. N. Powers and W. N. Setzer, "An in-silico investigation of phytochemicals as antiviral agents against dengue fever," Combinatorial Chemistry \& High Throughput Screening, vol. 19, no. 7, pp. 516-536, 2016.

[96] J. Vaya, P. A. Belinky, and M. Aviram, "Antioxidant constituents from licorice roots: isolation, structure elucidation and antioxidative capacity toward LDL oxidation," Free Radical Biology and Medicine, vol. 23, no. 2, pp. 302-313, 1997.

[97] J. Kühnl, D. Roggenkamp, S. A. Gehrke et al., "Licochalcone A activates Nrf2in vitroand contributes to licorice extractinduced lowered cutaneous oxidative stress in vivo," $E x$ perimental Dermatology, vol. 24, no. 1, pp. 42-47, 2015.

[98] X. Chen, Z. Liu, R. Meng, C. Shi, and N. Guo, "Antioxidative and anticancer properties of licochalcone A from licorice," Journal of Ethnopharmacology, vol. 198, pp. 331-337, 2017.

[99] S. Franceschelli, M. Pesce, I. Vinciguerra et al., "Licocalchone-C extracted from Glycyrrhiza glabra inhibits lipopolysaccharide-interferon- $\gamma$ inflammation by improving antioxidant conditions and regulating inducible nitric oxide synthase expression," Molecules, vol. 16, no. 7, pp. 57205734, 2011.

[100] H. Haraguchi, J. Inoue, Y. Tamura, and K. Mizutani, "Antioxidative components of Psoralea corylifolia (Leguminosae)," Phytotherapy Research, vol. 16, no. 6, pp. 539544, 2002.
[101] H. Liu, J. Wang, W. Zhou, Y. Wang, and L. Yang, "Systems approaches and polypharmacology for drug discovery from herbal medicines: an example using licorice," Journal of Ethnopharmacology, vol. 146, no. 3, pp. 773-793, 2013.

[102] T. Asano, K. Ishihara, T. Morota et al., "Permeability of the flavonoids liquiritigenin and its glycosides in licorice roots and davidigenin, a hydrogenated metabolite of liquiritigenin, using human intestinal cell line Caco-2," Journal of Ethnopharmacology, vol. 89, no. 2-3, pp. 285-289, 2003.

[103] Y. Kuang, Y. Lin, K. Li et al., "Screening of hepatoprotective compounds from licorice against carbon tetrachloride and acetaminophen induced HepG2 cells injury," Phytomedicine, vol. 34, pp. 59-66, 2017.

[104] Y. Lin, Y. Kuang, K. Li et al., "Nrf2 activators from Glycyrrhiza inflata and their hepatoprotective activities against CCl4-induced liver injury in mice," Bioorganic \& Medicinal Chemistry, vol. 25, no. 20, pp. 5522-5530, 2017.

[105] X. P. Gao, D. W. Qian, Z. Xie et al., "Protective role of licochalcone B against ethanol-induced hepatotoxicity through regulation of Erk signaling," Iranian Journal of Basic Medical Sciences, vol. 20, no. 2, pp. 131-137, 2017.

[106] J. Han, D. Wang, D. Li et al., "Licochalcone E protects against carbon tetrachloride-induced liver toxicity by activating peroxisome proliferator-activated receptor gamma," Molecular Medicine Reports, vol. 16, no. 4, pp. 5269-5276, 2017.

[107] R. Gaur, K. S. Yadav, R. K. Verma, N. P. Yadav, and R. S. Bhakuni, "In vivo anti-diabetic activity of derivatives of isoliquiritigenin and liquiritigenin," Phytomedicine, vol. 21, no. 4, pp. 415-422, 2014.

[108] J. Li, S.-W. Kang, J.-L. Kim, H.-Y. Sung, I.-S. Kwun, and Y.-H. Kang, "Isoliquiritigenin entails blockade of TGF- $\beta 1$ SMAD signaling for retarding high glucose-induced mesangial matrix accumulation," Journal of Agricultural and Food Chemistry, vol. 58, no. 5, pp. 3205-3212, 2010.

[109] Z. Ke, Z. Su, X. Zhang et al., "Discovery of a potent angiotensin converting enzyme inhibitor via virtual screening," Bioorganic \& Medicinal Chemistry Letters, vol. 27, no. 16, pp. 3688-3692, 2017.

[110] W. Li, S. Li, K. Higai et al., "Evaluation of licorice flavonoids as protein tyrosine phosphatase $1 \mathrm{~B}$ inhibitors," Bioorganic \& Medicinal Chemistry Letters, vol. 23, no. 21, pp. 5836-5839, 2013.

[111] R. B. Birari, S. Gupta, C. G. Mohan et al., "Antiobesity and lipid lowering effects of Glycyrrhiza chalcones: experimental and computational studies," Phytomedicine, vol. 18, no. 8-9, pp. 795-801, 2011.

[112] H.-Y. Quan, N. I. Baek, and S. H. Chung, "Licochalcone A prevents adipocyte differentiation and lipogenesis via suppression of peroxisome proliferator-activated receptor $\gamma$ and sterol regulatory element-binding protein pathways," Journal of Agricultural and Food Chemistry, vol. 60, no. 20, pp. 5112-5120, 2012.

[113] H. E. Lee, G. Yang, S.-H. Han et al., "Anti-obesity potential of Glycyrrhiza uralensis and licochalcone A through induction of adipocyte browning," Biochemical and Biophysical Research Communications, vol. 503, no. 3, pp. 2117-2123, 2018.

[114] Z.-H. Tang, T. Li, Y.-G. Tong et al., "A systematic review of the anticancer properties of compounds isolated from licorice (gancao)," Planta Medica, vol. 81, no. 18, pp. 1670-1687, 2015.

[115] H. Zhao, X. Yuan, J. Jiang et al., "Antimetastatic effects of licochalcone B on human bladder carcinoma T24 by inhibition of matrix metalloproteinases- 9 and NF-KB activity," 
Basic \& Clinical Pharmacology \& Toxicology, vol. 115, no. 6, pp. 527-533, 2014.

[116] P. A. Ward, J. S. Warren, and K. J. Johnson, "Oxygen radicals, inflammation, and tissue injury," Free Radical Biology and Medicine, vol. 5, no. 5-6, pp. 403-408, 1988.

[117] S. Ning, J. Mu, Z. Shen et al., "Isoliquiritigenin attenuates the invasive capacity of breast cancer cells via up-regulating the tumor suppressor RECK," RSC Advances, vol. 6, no. 29, pp. 1-31, 2016.

[118] R.-I. Tsukiyama, H. Katsura, N. Tokuriki, and M. Kobayashi, "Antibacterial activity of licochalcone A against sporeforming bacteria," Antimicrobial Agents and Chemotherapy, vol. 46, no. 5, pp. 1226-1230, 2002.

[119] B. A. M. Cantelli, T. A. Bitencourt, T. T. Komoto, R. O. Beleboni, M. Marins, and A. L. Fachin, "Caffeic acid and licochalcone A interfere with the glyoxylate cycle of Trichophyton rubrum," Biomedicine \& Pharmacotherapy, vol. 96, pp. 1389-1394, 2017.

[120] C.-C. Chiang, M.-J. Cheng, C.-F. Peng, H.-Y. Huang, and I.-S. Chen, "A novel dimeric coumarin analog and antimycobacterial constituents from Fatoua pilosa," Chemistry \& Biodiversity, vol. 7, no. 7, pp. 1728-1736, 2010.

[121] C. Feng Yeh, K. Chih Wang, L. Chai Chiang, D. E. Shieh, M. Hong Yen, and J. San Chang, "Water extract of licorice had anti-viral activity against human respiratory syncytial virus in human respiratory tract cell lines," Journal of Ethnopharmacology, vol. 148, no. 2, pp. 466-473, 2013.

[122] L. A. Phamhuy, H. He, and C. Phamhuy, "Free radicals, antioxidants in disease and health," InternatIonal Journal of Biomedical Science, vol. 4, no. 2, pp. 89-96, 2008.

[123] A. T. D. Pinedo, P. Pñalver, and J. C. Morales, "Synthesis and evaluation of new phenolic-based antioxidants: structureactivity relationship," Food Chemistry, vol. 103, no. 1, pp. 55-61, 2007.

[124] J.-M. Sauer, E. R. Stine, L. Gunawardhana, D. A. Hill, and I. G. Sipes, "The liver as a target for chemical-chemical interactions," Advances in Pharmacology, vol. 43, pp. 37-63, 1997.

[125] A. Williams and R. Burk, "Carbon tetrachloride hepatotoxicity: an example of free radical-mediated injury," Seminars in Liver Disease, vol. 10, no. 4, pp. 279-284, 1990.

[126] M.-S. Tsai, C.-C. Chien, T.-H. Lin et al., "Galangin prevents acute hepatorenal toxicity in novel propacetamol-induced acetaminophen-overdosed mice," Journal of Medicinal Food, vol. 18, no. 11, pp. 1187-1197, 2015.

[127] A. C. Menezes, P. R. Pinheiro, M. C. D. Pinheiro, and T. P. Cavalcante, "Towards the applied hybrid model in decision making: support the early diagnosis of type 2 diabetes," Information Computing and Applications, vol. 7473, pp. 648-655, 2012.

[128] H.-J. Liang, F.-M. Suk, C.-K. Wang et al., "Osthole, a potential antidiabetic agent, alleviates hyperglycemia in $d b / d b$ mice," Chemico-Biological Interactions, vol. 181, no. 3, pp. 309-315, 2009.

[129] J. Li, Y. S. Lee, J.-S. Choi et al., "Roasted licorice extracts dampen high glucose-induced mesangial hyperplasia and matrix deposition through blocking Akt activation and TGF$\beta$ signaling," Phytomedicine, vol. 17 , no. 10, pp. 800-810, 2010.

[130] M. Tawata, K. Aida, T. Noguchi et al., "Anti-platelet action of isoliquiritigenin, an aldose reductase inhibitor in licorice," European Journal of Pharmacology, vol. 212, no. 1, pp. 87-92, 1992.
[131] C. Zhan and J. Yang, "Protective effects of isoliquiritigenin in transient middle cerebral artery occlusion-induced focal cerebral ischemia in rats," Pharmacological Research, vol. 53, no. 3, pp. 303-309, 2006.

[132] A. Hajirahimkhan, C. Simmler, Y. Yuan et al., "Evaluation of estrogenic activity of licorice species in comparison with hops used in botanicals for menopausal symptoms," PLoS One, vol. 8, no. 7, Article ID e67947, 2013.

[133] X. Zhu, J. Liu, O. Chen et al., "Neuroprotective and antiinflammatory effects of isoliquiritigenin in kainic acid-induced epileptic rats via the TLR4/MYD88 signaling pathway," Inflammopharmacology, vol. 27, no. 6, pp. 1143-1153, 2019.

[134] J. Lv, Y. Fu, Y. Cao et al., "Isoliquiritigenin inhibits melanogenesis, melanocyte dendricity and melanosome transport by regulating ERK-mediated MITF degradation," Experimental Dermatology, vol. 29, no. 2, pp. 149-157, 2020.

[135] H. Nagai, J.-X. He, T. Tani, and T. Akao, "Antispasmodic activity of licochalcone A, a species-specific ingredient of Glycyrrhiza inflata roots," Journal of Pharmacy and Pharmacology, vol. 59, no. 10, pp. 1421-1426, 2007.

[136] L. Zhai, M. Chen, J. Blom, T. G. Theander, S. B. Christensen, and A. Kharazmi, "The antileishmanial activity of novel oxygenated chalcones and their mechanism of action," Journal of Antimicrobial Chemotherapy, vol. 43, no. 6, pp. 793-803, 1999.

[137] N. Tadigoppula, V. Korthikunta, S. Gupta et al., "Synthesis and insight into the structure-activity relationships of chalcones as antimalarial agents," Journal of Medicinal Chemistry, vol. 56, no. 1, pp. 31-45, 2013.

[138] S. N. Kim, S. J. Bae, H. B. Kwak et al., "In vitro and in vivo osteogenic activity of licochalcone A," Amino Acids, vol. 42, no. 4, pp. 1455-1465, 2012. 